\title{
Determination of thermobacteriological parameters and size of Bacillus stearothermophilus ATCC 7953 spores
}

\author{
Determinação dos parâmetros de destruição térmica e \\ dimensões de esporos de Bacillus stearothermophilus ATCC 7953
}

\author{
Marcos FRAIHA $^{1 \star}$, Antonio Carlos de Oliveira FERRAZ ${ }^{1}$, João Domingos BIAGI ${ }^{1}$
}

\begin{abstract}
In order to determine thermobacteriological parameters for B. stearothermophilus spores, they were diluted in a saline solution medium and in ground corn-soybean mix, distributed in TDT tube, and submitted to heat for a specific period of time. The D value (time to reduce $1 \log$ cycle of microbial count under a certain temperature) and $\mathrm{z}$ value (variation of temperature to cause 10 -fold change in $\mathrm{D}$ value) were estimated. To estimate their dimensions, the spores were visualized by using a scanning electron microscope. $\mathrm{D}_{121.1{ }^{\circ} \mathrm{C}}$ and $\mathrm{z}$ values for these spores, as determined in the saline solution, were 8.8 minutes and $12.8^{\circ} \mathrm{C}$, respectively. $\mathrm{D}_{121,1{ }^{\circ} \mathrm{C}}$ and $\mathrm{z}$ values determined in the corn-soy mix were 14.2 minutes and $23.7^{\circ} \mathrm{C}$, respectively. The micrographs indicated that the spores have homogeneous shape and size, with length and diameter of 2 and $1 \mu \mathrm{m}$, respectively. These results confirm that the spore is highly thermal-resistant, and it is a good biological indicator to evaluate the extrusion process as a feed sterilizer.

Keywords: thermobacteriology; feed; D value; $z$ value; spore size.
\end{abstract}

\section{Resumo}

Este experimento objetivou determinar os parâmetros de destruição térmica de esporos de Bacillus stearothermophilus ATCC 7953 e a estimativa de suas dimensões. Os esporos foram suspensos em solução salina e em mistura de grãos de milho e soja moídos, distribuídos em tubos TDT, e submetidos ao calor por tempo variável, seguido de incubação e contagem direta. Determinou-se o valor D (tempo necessário para redução da viabilidade do micro-organismo em 1 ciclo logarítmico sob determinada temperatura) e o valor $\mathrm{z}$ (intervalo de temperatura que ocasiona variação de 10 vezes no valor D). Os esporos suspensos em solução salina foram observados em microscópio eletrônico de varredura, para estimativa das dimensões. Os valores de $\mathrm{D}_{121,1{ }^{\circ} \mathrm{C}}$ e z para os esporos suspensos em solução salina foram 8,8 minutos e $12,8^{\circ} \mathrm{C}$, respectivamente. Para aqueles suspensos em mistura milho e soja, $\mathrm{D}_{121,1{ }^{\circ} \mathrm{C}}$ e $\mathrm{z}$ foram 14,2 minutos e $23,7^{\circ} \mathrm{C}$, respectivamente. As micrografias indicaram que os esporos apresentam-se como bastonetes, homogêneos em forma e dimensão, com comprimento e diâmetro estimados em 2 e $1 \mu \mathrm{m}$, respectivamente. Os resultados confirmam a elevada resistência térmica do esporo e indicam que este é um bom indicador biológico para avaliação do processo de extrusão como esterilizante de alimentos.

Palavras-chave: termobacteriologia; ração; valor D; valor $z$; dimensões do esporo.

\section{Introduction}

Of all the physical means of microbiological control, heat is the most commonly used, and it is the cheapest and easiest to control sterilizing agent. Moist heat, as opposed to dry heat, is more effective due to the requirement of a lower temperature and amount of time needed to ensure the intended sterilization (PENNA; MACHOSHVILI, 1997).

Assessing sterilization processes requires the use of a biological indicator, by selecting a microorganism resistant to the sterilizing agent, in order to verify the effectiveness of the physical measures taken.

Thermophilic bacteria spores are the most resistant to heat, followed by some anaerobic mesophiles. The vegetative cells of bacteria, moulds, yeasts, and viruses present very little resistance to heat (LEITÃO; JUNQUEIRA, 1995). The thermal resistance of microorganisms is related to the stability of the thermophilic proteins, which are attributed to its hydrophobicity, a more densely compacted structure, and better electrostatic interaction in the formation of the protein function (KUMAR; NUSSINOV, 2001).

Bacillus stearothermophilus spores, given their heat resistance, are the microorganisms chosen as biological indicators for moist heat sterilization processes (LETRARI; LIMA; VANIN, 2006). These are gram-positive, facultative aerobic or anaerobic rods, and capable of growing in temperatures between 33 and $70^{\circ} \mathrm{C}$. They are sugar-fermenting, non-gas producing and non-proteolytic bacteria. The ideal $\mathrm{pH}$ for their growth ranges from 6.0 to 7.5.

The food extrusion process is widely used in the feed industry. In view of the temperatures generated in this process, which can reach $140{ }^{\circ} \mathrm{C}$ or higher, the extruder gains the capacity of microbiological control of the feedstuffs.

${ }^{1}$ Faculdade de Engenharia Agrícola, Universidade Estadual de Campinas - UNICAMP, CEP 13083-875, Campinas - SP, Brasil, E-mail: marcosfraiha@hotmail.com

${ }^{*}$ A quem a correspondência deve ser enviada 
However, numerous results indicate that heat may not be the sole phenomenon involved in the destruction of microorganisms subjected to extrusion (KAUFFMAN; HATCH, 1977; BOUVERESSE et al., 1982; BULUT; WAITES; MITCHELL, 1999; OKELO et al., 2006). Therefore, there may be some mechanical phenomena involved in the cellular rupture of these microorganisms. In accordance with the energetic equivalence concept (ZHENG; WANG, 1994), heat and shear are responsible for the molecular transformation of food during extrusion. Shear causes the rupture of starch structure reducing it to granules smaller than $0.5 \mu \mathrm{m}$ (ZHENG; CHIANG; WANG, 1995). Thus, the suspicion that the integrity of the microorganism would be affected by the shear force developed in the extrusion process is reasonable, depending on its size.

This study is part of a wider project which aims to evaluate the extrusion process as a pasteurizer of foodstuffs using B. stearothermophilus spores as the biological indicator. Although the thermobacteriological parameters of this microorganism have been known for years (SEGNER; FRAZIER; CALBERT, 1963; STUMBO, 1965; BOUVERESSE et al., 1982; FEEHERRY; MUNSEY; ROWLEY, 1987; PINHO; CRISTIANINI, 2005; LETRARI; LIMA; VANIN, 2006), the differences between the strains and medium used to determine the thermal resistance can affect the results. Iciek, Papiewska and Molska (2006) have shown that medium $\mathrm{pH}$ and sodium concentration may influence B. stearothermophilus resistance to heat. In addition, the temperature of sporulation and components of the medium may also influence heat effects on spore mortality (LEQUÉRINEL; COUVERT; MAFART, 2007; YOO; HARDIN; CHEN, 2006).

Therefore, the objective of this work is to determine the thermobacteriological parameters of $B$. stearothermophilus ATCC 7953 spores, determined in saline solution and practical mixture of animal feed, and to estimate the sizes of such spores. These results will be used to assess the kinetics of the destruction of microorganisms during the extrusion of feeds.

\section{Materials and methods}

The experiment was performed at the Post-Harvest Technology Laboratory at the Unicamp Agricultural Engineering School.

Bacillus stearothermophilus ATCC 7953 spores were acquired at the Fundação André Tosello, in the city of Campinas. The microorganisms were presented in a $0.85 \%$ saline solution, with $10^{7} \mathrm{UFC} . \mathrm{mL}^{-1}$, and kept under refrigeration $\left(5^{\circ} \mathrm{C}\right)$ during the entire experimental period.

To determine the thermal destruction curve, the spores were suspended in saline solution $(0.85 \%, \mathrm{pH} 6.7)$ to a final concentration of $10^{6}$ UFC. $\mathrm{mL}^{-1}$. Three $\mathrm{mL}$ aliquots were distributed into TDT tubes, measuring approximately $10 \mathrm{~mm}$ in diameter, sterilized in advance, and then subjected to the test temperatures, which were $100,110,117$, and $126^{\circ} \mathrm{C}$, for a period of time which ranged from 0 to 30 minutes. The temperature was maintained constant in a vegetable oil double boiler. At the end of the predetermined time for each sample, the tube was removed from the double boiler and quickly cooled in water.
This same procedure was used for samples of ground corn and soybean at a 70:30 ratio (mass) as the medium $(\mathrm{mL})$ which were previously subjected to sterilization by gamma irradiation at $25 \mathrm{kGy}$ (IPEN Irradiator, Universidade de São Paulo). The spores were suspended in saline solution $(0.85 \%, \mathrm{pH} 6.7)$ and mixed with the sterile corn-soybean mash with the aid of a domestic food blender in a proportion of $200 \mathrm{~mL}$ of solution to $800 \mathrm{~g}$ of mash. The final moisture content of the material was $30.00 \pm 0.30 \%$, and it had an average geometric diameter of $542.39 \pm 42.98 \mu \mathrm{m}$ (average \pm standard deviation). To avoid any contamination, such a procedure was performed in a laminar flow hood. After being mixed, the material was stored under refrigeration $\left(5^{\circ} \mathrm{C}\right)$ for 48 hours until the experiments began. Preliminary assays indicated that the viability of the spores remained unaltered for a period of over 45 days under the storage conditions employed for this experiment. Spore counting at several different points of mass indicated that the sowing and mixing methods were satisfactory, representing a variation coefficient of less than $10 \%$.

Two grams of sample were distributed in previously sterilized TDT tubes, and subjected to temperatures of 103,118 , and $122{ }^{\circ} \mathrm{C}$ in a vegetable oil double boiler for a time ranging from 0 to 40 minutes.

The water activity of the samples was determined using a $\mathrm{Pa}_{\mathrm{w}} \mathrm{kit}^{\circledast}$ water activity meter (Decagon, Pullman, USA).

Following the treatments, the spore germination was carried out using the thermal shock method. The samples were heated in a double boiler at $80^{\circ} \mathrm{C}$ for 15 minutes and quickly cooled in an ice bath. The sowing of the microorganisms was carried out in dextrose tryptone agar, followed by incubation for 48 hours at $50^{\circ} \mathrm{C}$, as described by Orson and Sorrels (1992). The growth medium was prepared and its $\mathrm{pH}$ was corrected to 7.1, using $\mathrm{NaOH} 0.1 \mathrm{~N}$. The culture medium and all the glassware used were previously subjected to sterilization in an autoclave at $121{ }^{\circ} \mathrm{C}$ for 20 minutes. All the microbiological work was performed in a laminar flow hood. Treatments were done in triplicates and spore counting in quadruplicates.

The data obtained were assessed following the Bigelow model. Data were represented in a semi-logarithmic graph, with the logarithm of the surviving organism as the ordinate and the heating time as the abscissa. The decimal reduction time ( $D$ value) was calculated for each of the experiment temperatures using Equation 1:

$$
D=\frac{t}{(\log A-\log B)}
$$

where $t$ is the cooking time of the samples (minute); $A$ is the initial number of microorganisms (UFC. $\mathrm{mL}^{-1}$ ); and $B$ is the final number.

The $D$ values for each temperature were represented in a semi-logarithmic graph, with $D$ value as the ordinate, and test temperature as the abscissa. The $z$ value represented the module of the necessary temperature for a 10 -fold change of the $D$ value, given by Equation 2: 


$$
z=\left|\frac{T_{A}-T_{B}}{\log D_{A}-\log D_{B}}\right|
$$

The $\mathrm{D}$ values for other temperatures not considered in the experiment could be estimated from the following equation (Equation 3):

$\frac{D_{r e f}}{D_{T}}=10^{\left(\frac{T-T_{r f}}{z}\right)}$

where $D_{\text {ref }}$ is the known $D$ value, $D_{T}$ is the sought $D$ value, $T$ is the temperature of interest, and $T_{r e f}$ is the known temperature, which results in $D T$.

To visualize the shape and estimated dimension of the spores, they were photographed with the aid of a Scanning Electron Microscope (SEM) (Leo, 440i, England). The samples collected from the saline solution were dried in a dessicator and coated with gold and palladium.

\section{Results and discussion}

For the spores suspended in the saline solution, the decimal reduction values for the assay temperatures were $\mathrm{D}_{100{ }^{\circ} \mathrm{C}}=$ 72.9 minutes, $\mathrm{D}_{110^{\circ} \mathrm{C}}=53.4$ minutes, $\mathrm{D}_{117^{\circ} \mathrm{C}}=18.5$ minutes, and $\mathrm{D}_{126^{\circ} \mathrm{C}}=4.7$ minutes (Figure 1).

The heat contribution to destroy the heat-resistant bacterial spores is only slight up to $100{ }^{\circ} \mathrm{C}$. The laboratorial routine for the germination of heat-resistant spores, such as B. stearothermophilus, uses the thermal shock technique, with a hot bath of between 80 and $110^{\circ} \mathrm{C}$ for 10 to 30 minutes, followed by fast cooling (ORSON; SORRELS, 1992). Hence, $\mathrm{D}_{100{ }^{\circ} \mathrm{C}}$ was disregarded for the calculation of the $z$ value, which was estimated at $12.8^{\circ} \mathrm{C}$ when ascertained in saline solution (Figure 2 ).

These results are similar to the data obtained by other authors (Table 1). Segner, Fazier and Calbert (1963), studying the kinetics of the thermal destruction of B. stearothermophilus NCA-FS 1518 in phosphate buffer (pH 6.2) obtained $\mathrm{D}_{121.1^{\circ} \mathrm{C}}=$ 11.7 minutes and $\mathrm{z}=21.9^{\circ} \mathrm{C}$. Stumbo (1965) ascertained the $\mathrm{D}_{121 .{ }^{\circ} \mathrm{C}}$ and $z$ values for $B$. stearothermophilus as 4.0-5.0 minutes and $12.2^{\circ} \mathrm{C}$, respectively. Bouveresse et al. (1982) obtained $\mathrm{D}_{121.1{ }^{\circ} \mathrm{C}}=3.9$ minutes and $\mathrm{z}=18{ }^{\circ} \mathrm{C}$ for $B$. stearothermophilus NCA-FS 1518, determined in sodium phosphate buffer. Feeherry,

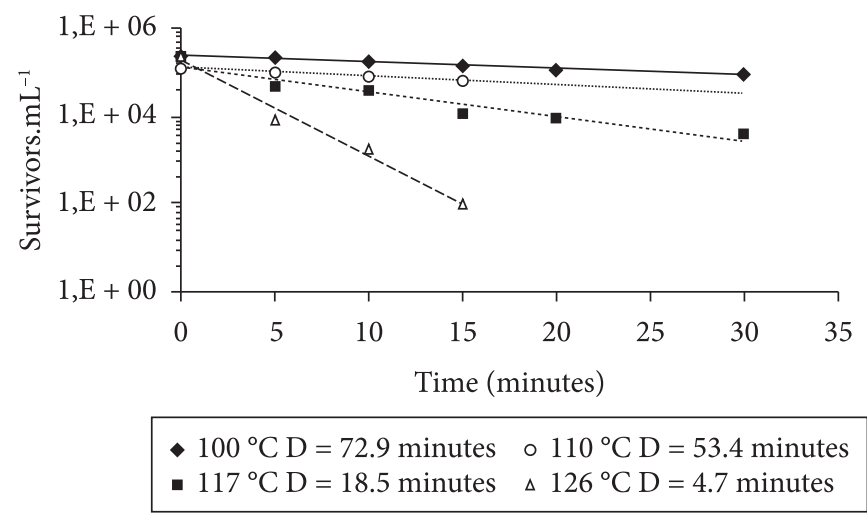

Figure 1. Thermal destruction curve of B. stearothermophilus spores at different temperatures determined in $0.85 \%$ saline solution.
Munsey and Rowley (1987) ascertained $\mathrm{D}_{121.1^{\circ} \mathrm{C}}=3.33$ minutes and $\mathrm{z}=8.3^{\circ} \mathrm{C}$ for B. stearothermophilus ATCC 12980 spores, using distilled water as the medium. Pinho and Cristianini (2005) obtained $\mathrm{D}_{121.1{ }^{\circ} \mathrm{C}}=1.57$ minutes and $\mathrm{z}=8.32^{\circ} \mathrm{C}$ for the ATCC 7953 strain determined in human baby food. Letrari, Lima and Vanin (2006) ascertained $\mathrm{D}_{121.1^{\circ} \mathrm{C}}=1.53-1.8$ minutes e $\mathrm{z}=15.3-18.0^{\circ} \mathrm{C}$ for B. stearothermophilus ATCC 7953 in $0.1 \%$ tryptone broth.

The bacterial strain used and the medium for diluting the spores can influence the results. Bulut, Waites and Mitchell (1999) observed up to a 3-fold difference in the D value due to the medium used. In this experiment, the data indicate that there was less destruction of the spores when they were heated in the corn-soybean mix compared to that observed in the saline solution data. The decimal reduction values ascertained for the mixture were: $\mathrm{D}_{103{ }^{\circ} \mathrm{C}}=91.7$ minutes, $\mathrm{D}_{118{ }^{\circ} \mathrm{C}}=18.9$ minutes, and $\mathrm{D}_{122{ }^{\circ} \mathrm{C}}=15.6$ minutes (Figure 3 ). The estimated $\mathrm{z}$ value was $23.7^{\circ} \mathrm{C}$ (Figure 4).

In Figure 3, the lower $\mathrm{D}$ values at $118^{\circ} \mathrm{C}$ compared to those at $122^{\circ} \mathrm{C}$ can be explained by the lower initial number of spores in the test sample for that temperature.

It has been long known that moist heat is much more efficient than dry heat in destroying microorganisms (PENNA; MACHOSHVILI, 1997; LEITÃO; JUNQUEIRA, 1995). The water activity of the medium used to determine the bacteriological parameters influences the results (STUMBO, 1965). The corn

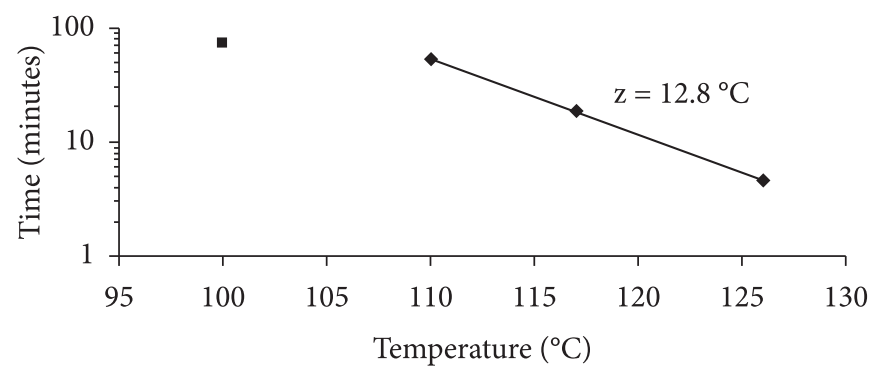

Figure 2. Thermal resistance curve of B. stearothermophilus spores estimated based on the $\mathrm{D}$ values determined in $0.85 \%$ saline solution.

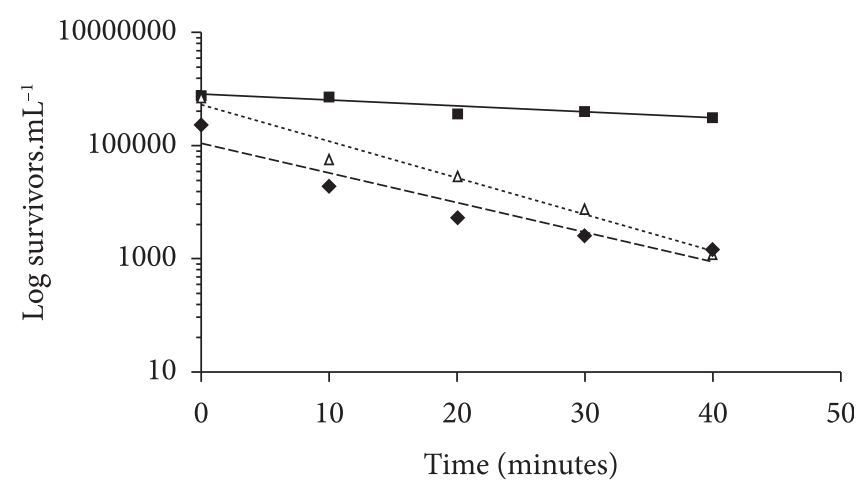

- $103^{\circ} \mathrm{C} \mathrm{D}=91.7$ minutes $\triangle 122^{\circ} \mathrm{C} \mathrm{D}=18.9$ minutes - $103^{\circ} \mathrm{C} \mathrm{D}=15.6$ minutes

Figure 3. Thermal destruction curve of B. stearothermophilus spores at 103,118 and $122^{\circ} \mathrm{C}$ determined in the corn-soybean mixture. 
Table 1. Thermobacteriological parameters for B. Stearothermophilus.

\begin{tabular}{|c|c|c|c|c|}
\hline Source & Stock & Medium & $\mathrm{D}_{121,1^{\circ} \mathrm{C}}$ (minutes) & $\mathrm{z}\left({ }^{\circ} \mathrm{C}\right)$ \\
\hline Segner, Fazier and Calbert (1963) & NCA-FS 1518 & Phosphate buffer & 11.7 & 21.9 \\
\hline Stumbo (1965) & & & $4.0-5.0$ & 12.2 \\
\hline Bouveresse et al. (1982) & NCA-FS 1518 & Phosphate buffer & 3.9 & 18 \\
\hline Feeherry, Munsey and Rowley (1987) & ATCC 12980 & Distilled water & 3.33 & 8.3 \\
\hline Pinho and Cristianini (2005) & ATCC 7953 & Baby food & 1.57 & 8.32 \\
\hline Letrari, Lima and Vanin (2006) & ATCC 7953 & Phosphate buffer & $1.5-1.8$ & $15.3-18.0$ \\
\hline
\end{tabular}

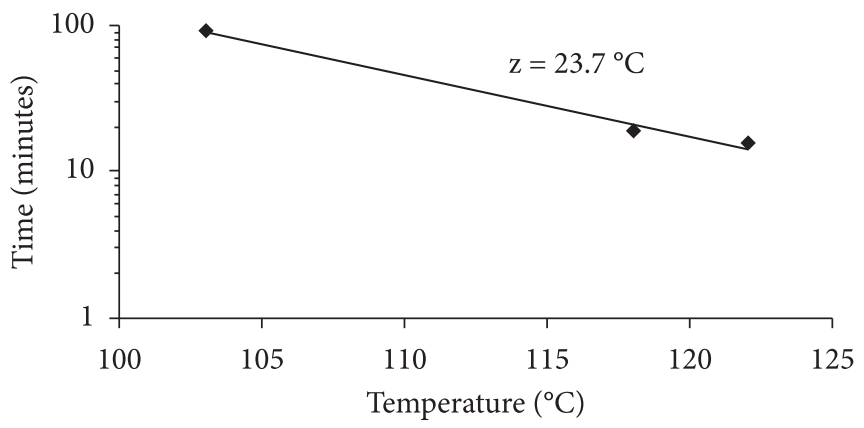

Figure 4. Thermal resistance curve of B. stearothermophilus spores estimated based on the $\mathrm{D}$ values determined in the corn-soybean mixture.

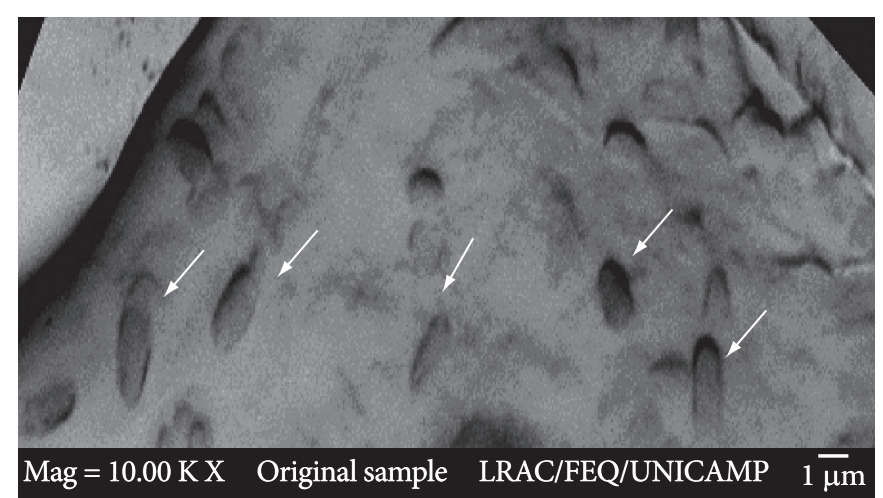

Figure 5. Micrograph of B. stearothermophilus spores (SEM, $10,000 \times)$

and soybean mix medium used in this experiment presented a final moisture content of $30 \%$ and water activity of 0.92 , after sowing the spores, together with the difference in the thermal conductivity of water and of the grains; these could be hypotheses to explain the lesser destruction of spores compared to that when the saline solution was used as the medium. The water activity of the saline solution was calculated as 0.97 .

The results obtained in this experiment shall be used for comparison against results observed in the extrusion process of foods. The resistance time of the material in the extruder and the process temperature vary from 60 to 150 seconds and 80 to $140{ }^{\circ} \mathrm{C}$, respectively. The parameters determined here are adequate for use in this variation range.

Figure 5 presents the micrographs of the $B$. stearothermophilus spores, which are shown to be of homogenous shape and size and have an estimated length and diameter of 2 and $1 \mu \mathrm{m}$, respectively.

\section{Conclusions}

These results confirm the heightened heat resistance of B. stearothermophilus spores, as previously reported, and the influence of the culture medium on the results of the thermobacteriological parameters. The spores of B. stearothermophilus presented homogenous shape, a length of $2 \mu \mathrm{m}$ and diameter of $1 \mu \mathrm{m}$, and are good biological indicators for assessing thermal sterilization processes.

\section{Acknowledgments}

The authors thank Dr. Paulo Rela, from the Instituto de Pesquisas Nucleares, Universidade de São Paulo, for the gamma irradiation treatments. This study was funded by FAPESP. The first author received a research fellowship grant from $\mathrm{CNPq}$.

\section{References}

BOUVERESSE, J. A. et al. Influence of extrusion cooking on the thermal destruction of Bacillus stearothermophilus spores in a starch-proteinsucrose mix. Lebensmittel-Wissenschaft und-Technologie, v. 15, p. 135-38, 1982.

BULUT, S.; WAITES, W. M.; MITCHELL, J. R. Effects of combined shear and thermal forces on destruction of Microbacterium lacticum. Applied Environmental Microbiology, v. 65, n. 10, p. 4464-69, 1999.

FEEHERRY, F.; MUNSEY, D.; ROWLEY, D. B. Thermal inactivation and injury of Bacillus stearothermophilus spores. Applied Environmental Microbiology, v. 53, n. 2, p. 365-70, 1987.

ICIEK, J.; PAPIEWSKA, A.; MOLSKA, M. Inactivation of Bacillus stearothermophilus spores during thermal processing. Journal of Food Engineering, v. 77, n. 3, p. 406-10, 2006.

KAUFFMAN, K.B.; HATCH, R.T. Shear effects on cell viability during extrusion of semi-moist foods. Journal of Food Science, v. 42, n. 4, p. 906-10, 1977.

KUMAR, S.; NUSSINOV, R. How do thermophilic proteins deal with heat? Cellular and Molecular Life Sciences, v. 58, p. 1217-33, 2001.

LEITÃO, M. F. F.; JUNQUEIRA, V. C. A. Microbiologia aplicada à esterilização de alimentos. In: GERMER, S. P. M. et al. Princípios de esterilização de alimentos. 2. ed. Campinas: ITAL, 1995. v. 10, p. 3-22. Manual técnico.

LEQUÉRINEL, I.; COUVERT, O.; MAFART, P. Modelling the influence of the sporulation temperature upon the bacterial spore heat resitance, application to heating process calculation. International Journal of Food Microbiology, v. 114, n. 1, p. 100-4, 2007.

LETRARI, J.; LIMA, H. O. S.; VANIN, M. Esterilização térmica e parâmetros de morte microbiana do Bacillus stearothermophilus 
ATCC 7953. In: ENTEC, 4.; WORKSHOP DA UTFPR, 2., 2006, Campo Mourão. Anais... Campo Mourão: 2006.

OKELO, P. O. et al. Optimization of extrusion conditions for elimination of mesophilic bacteria during thermal processing of animal feed mash. Animal Feed Science and Technology, v. 129, p. 116-37, 2006.

ORSON, K. E.; SORRELS, K. M. Thermophilic anaerobic sporeformers. In: VANDERZANT, C., SPLITTSTOESSER, D. F. Compendium of methods for the microbiological examination of foods. 3. ed. Washington American Public Health Association: 1992. p. 245-248.

PENNA, T. C. V.; MACHOSHVILI, I. A. Esterilização térmica: conceitos básicos da morte microbiana. Revista Farmácia Bioquímica da Universidade de São Paulo, p.1-5, 1997. Suplemento 1.

PINHO, C.; CRISTIANINI, M. Three-dimensional mathematical modeling of microbiological destruction of Bacillusstearothermophilus in conductive baby food packed in glass container. International Journal of Food Engineering, v. 1, n. 2, 2005.

SEGNER, W. P.; FRAZIER, W. C.; CALBERT, H. E. Thermal inactivation of heat-resistant bacterial spores in milk concentrate at ultra-high temperatures. Journal of Dairy Science, v. 46, n. 9, p. 891-6, 1963.

STUMBO, C. R. Thermobacteriology in Food Processing. Academic Press: Nova Iorque, 1965. $236 \mathrm{p}$.

YOO, J. A.; HARDIN, M. T.; CHEN, X. D. The influence of milk composition on the growth of Bacillus stearothermophilus, Journal of Food Engineering, v. 77, n. 1, p. 96-102, 2006.

ZHENG, X.; CHIANG, W. C.; WANG, S. S. Effect of shear energy on size reduction of starch granules in extrusion. Starch/Stärke, v. 47, n. 4, p. 146-51, 1995.

ZHENG, X.; WANG, S. S. Shear induced starch conversion during extrusion. Journal of Food Science, v. 59, n. 5, p. 1137-1143, 1994. 